\title{
Development and evaluation of bilayer tablets of combination of antibiotics for the treatment of sexually transmitted disease
}

\author{
Swati Sanjay Gaikwad*, Sandip Annaji Chafle, Princy Sunil Morris, Jasmine Gev Avari \\ Department of Pharmaceutical Sciences, R. T. M. Nagpur University, Mahatma, Jyotiba Fuley Educational Campus, Nagpur, \\ Maharashtra, India
}

\begin{abstract}
The present research work was envisaged to develop bilayer tablets to improve therapeutic efficacy of antibiotic combination for the treatment of sexually transmitted diseases. The combination of two antibiotics i.e. cefixime trihydrate and ofloxacin were used for the preparation of bilayer tablets which act against genito-urinary infections. The formulations comprise of cefixime trihydrate as immediate release layer formulated using different superdisintegrants and ofloxacin as extended release layer containing HPMC K100M. Evaluation of bilayer tablets were performed for the immediate release cefixime layer and sustain release ofloxacin layer with optimization of excipients. The immediate release layer of cefixime showed complete release within $30 \mathrm{~min}$ and ofloxacin release was extended up to 24 hours. The similarity factor value of ofloxacin sustained release layer was found to be 87.01 for initial and 80.35 after 3 months stability when compared with marketed reference product. The present study revealed that cefixime trihydrate and ofloxacin bilayer tablets were successfully developed for the use against sexually transmitted infections.
\end{abstract}

Uniterms: Sexually transmitted diseases/treatment. Bilayer tablets. Cefixime trihydrate. Ofloxacin.

\section{INTRODUCTION}

The curable sexually transmitted diseases (STDs) are the major public health problems worldwide which lead to illness with significant health, social and economic consequences, but except HIV no particular attention has been given to the prevalence of other infections (Parashar et al., 2006; Tree, Morse, 1995; WHO, 2002). It can lead to long-term, serious complications and sequelae (Robert et al., 1999). In the year 2006, about $85 \%$ of the HIV infections have spread due to STD patients, which is alarming. STDs are among the most common infectious diseases. Annually, an estimated 19.7 million sexually transmitted infections occur in the United States alone. Worldwide, an estimated 499 million cases of chlamydia, gonorrhea, syphilis, and trichomoniasis occur each year. Some STDs are more prevalent in developing countries (chancroid, lymphogranuloma venereum [LGV], granuloma inguinale [donovanosis]) or in specific regions (gonorrhea with treatment failure

*Correspondence: Ms. Swati Sanjay Gaikwad. Department of Pharmaceutical Sciences. R. T. M. Nagpur University, Mahatma. Jyotiba Fuley Educational Campus. Amravati Road, Nagpur, 440033. Maharashtra, India. E-mail: swati.gaikwad05@gmail.com and decreased susceptibility to cephalosporins in Asia) and may be imported into other countries by travelers returning from such locales. (Kidd, Workowski, 2016). There are various problems with the treatment of sexually transmitted disease (STDs) like increasing widespread resistance against individual drug, limited alternatives in pregnancy or allergy, lack of single agents possessing a broad spectrum of activity against multiple genital pathogens and higher dose of drug required for treatment with frequent dosing (Handsfield 1986; Steen et al., 2012).

Fixed dose combination therapy has various advantages over conventional monotherapy such as simpler dosage schedule leading to improved patient compliance and therefore improved treatment outcomes, reduced side effects, reduced development of resistance in the case of antimicrobials and potentially lower cost of manufacturing, handling, packing and shipping compared to the costs of producing separate products (Sica, 1994). The conventional dosage form produces wide fluctuation in drug concentration in the blood stream which led to the concept of sustained drug delivery. The goal in designing sustained delivery systems is to reduce the frequency of the dosing or to increase effectiveness of the drug or providing uniform delivery of drug. 
The present research was carried out with the aim of developing bilayer tablets of cefixime trihydrate and ofloxacin for the treatment of sexually transmitted disease (STDs). Cefixime trihydrate and ofloxacin were selected as a combination of drugs against STDs since this combination was widely used in treatment of uncomplicated urethral, endocervical and rectal infections caused by susceptible Neisseria gonorrhea and Chlamydia trachomatis (Schmidt, Charles, 1995; Bennett, Brown, 2008). Literature studies revealed that extensive work have been done on individual drugs i.e. ofloxacin sustained release formulation using HPMC K100M (Chavanpatil et al., 2005), methacrylic acid copolymers (Yue et al., 2008) and cefixime trihydrate immediate release tablets using different superdisintegrants (Remya et al., 2010). But no work has been reported yet on the use of these two drugs in combinations as bilayer tablets. Hence, it was thought worthwhile to formulate a novel bilayer tablet comprising of cefixime trihydrate as immediate release layer and ofloxacin as sustained release layer. So as to reduce the total dose of drug need to be taken twice in a day and dosing frequency. Dose reduction by giving maintainence dose of ofloxacin will eventually reduce adverse effect, whereas reduction in dosing frequency will lead to patient compliance. The effect of varying concentration of different superdisintegrants on disintegration and dissolution of cefixime trihydrate immediate release layer was evaluated. Also, HPMC K100M was evaluated as release modifying sustained release excipient in the development of sustained release layer. Ofloxacin release can be extended up to 24 hours since, the average transit time through just the large intestine (colon) was 40 hours (Mayoclinic). The compatibility of drugs with excipients was studied by FT-IR. The formulated bilayer tablets were compared with the marketed formulations to study the similarity factor of release profiles. Such bilayer tablet having varying release pattern of antibiotics has not been reported.

\section{MATERIAL AND METHODS}

\section{Materials}

Cefixime trihydrate and ofloxacin were received as research samples from Zim Laboratories Ltd. (Nagpur, India) and Vama Pharma (Nagpur, India) respectively. Hydroxypropyl methyl cellulose (HPMC K100M), Polyplasdone XL (Crospovidone) and Glycolys (sodium starch glycolate) were generously gifted by Colorcon Asia Pvt. Ltd. (Goa, India), International Specialty Product Ltd.
(Mumbai, India) and Roquette India Pvt. Ltd. (Mumbai, India) respectively. Ac-Di-Sol (Croscarmellose sodium) and Avicel (PH 101 and PH 102) (Microcrystalline cellulose) were supplied by Signet Chemical Corporation Pvt. Ltd. (Mumbai, India). Lactose monohydrate was purchased from LobaChemie Pvt. Ltd. (Mumbai, India). Aerosil 200P (Colloidal silicon dioxide) was obtained from Evonik Degussa India Pvt. Ltd. (Mumbai, India). All other chemicals and reagents were of analytical grade. Table I gives the physicochemical parameters of cefixime trihydrate ofloxacin.

\section{METHODS}

\section{Preformulation studies}

To check the drug-drug and drug-excipient interactions, preformulation studies were performed. Drugs alone, in combination and along with excipients proposed to be used were filled in amber colored vials sealed with bromo butyl rubber stoppers and kept in environmental stability chamber (Remi Lab, Mumbai, India) for accelerated stability condition at $40 \pm 2{ }^{\circ} \mathrm{C}$ temperature and $75 \pm 5 \%$ relative humidity for a period of 30 days. Infra-red spectra of samples were obtained with FT-IR spectrophotometer (FTIR-8001, Shimadzu, Japan) operated with omnic software and compared with the initial spectra of drugs.

\section{Development of Cefixime trihydrate immediate release (IR) tablets}

The composition of various batches is given in Table II. Different batches of cefixime trihydrate IR tablets were formulated using different superdisintegrants in varying concentration of 3,5 and $7 \% \mathrm{w} / \mathrm{w}$. Cefixime trihydrate and excipients were passed through ASTM (American Society for Testing and Materials) 40 mesh sieve $(425 \mu)$ and dry blended for $10 \mathrm{~min}$ in double cone blender at $14 \pm 2 \mathrm{rpm}$. Aerosil 200P $(0.5 \% \mathrm{w} / \mathrm{w})$ and magnesium stearate $(0.5 \% \mathrm{w} / \mathrm{w})$ were sifted through ASTM 60 mesh sieve $(250 \mu)$ and added extra granularly and lubricated for $3 \mathrm{~min}$. The moisture content of the lubricated blend was determined by heating the sample in hot air oven (SMC-120, Spectrum Pvt. Ltd., Mumbai, India) at $105^{\circ} \mathrm{C}$. Compression was carried out using ten station single rotary tablet compression machine (Pilot Press Tablet Machine, Chamunda Pharma Machinery Pvt. Ltd., Ahmedabad, India) equipped with bevelled flat-faced punches of $9 \mathrm{~mm}$ diameter at a tablet weight of $350 \mathrm{mg}$. 
TABLE I - Physicochemical parameters of cefixime trihydrate and ofloxacin

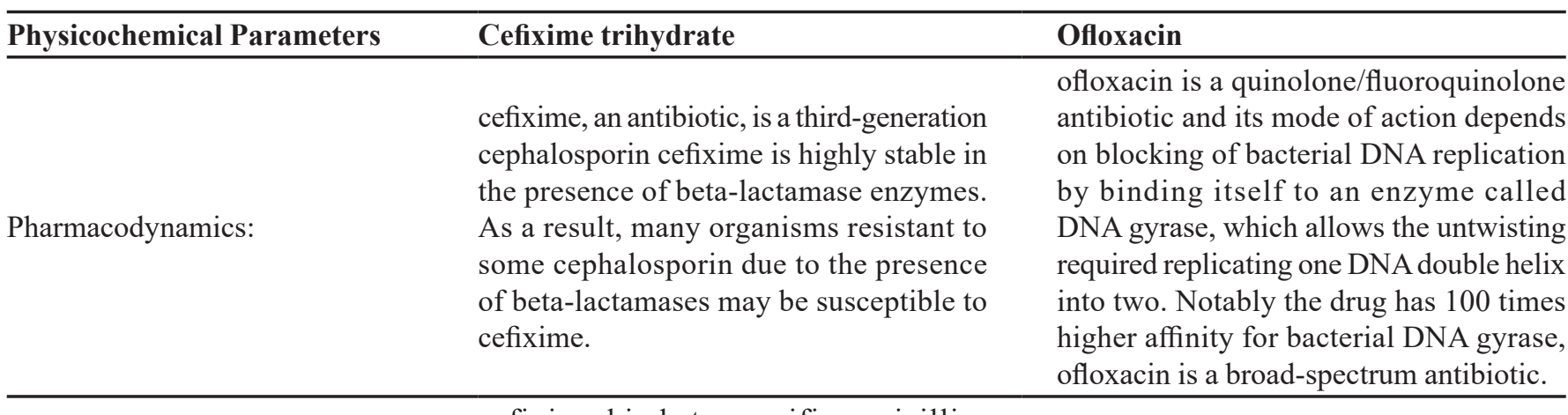

cefixime binds to specific penicillinbinding proteins (PBPs) located inside the bacterial cell wall, causing the inhibition of Mechanism of action the third and last stage of bacterial cell wall synthesis. Cell lysis is then mediated by bacterial cell wall autolytic enzymes such as autolysins; it is possible that cefixime interferes with an autolysin inhibitor.

\begin{tabular}{lll}
\hline Absorption & About $40 \%-50 \%$ absorbed orally & $\begin{array}{l}\text { Bioavailability of ofloxacin in the tablet } \\
\text { formulation is approximately } 98 \%\end{array}$ \\
\hline & $3-4$ hours (may range up to 9 hours). & \\
Half life & $\begin{array}{l}\text { In severe renal impairment ( } 5 \text { to } 20 \mathrm{ml} / \\
\text { min creatinine clearance), the half-life }\end{array}$ & 9 hours \\
& increased to an average of 11.5 hours. & \\
\hline
\end{tabular}

\section{Development of ofloxacin sustained release (SR) tablets}

Ofloxacin SR tablet formulations (F1-F8) were prepared by wet granulation technique as given in Table III. All the powders were passed through ASTM 40 mesh sieve $(425 \mu)$. Required quantities of ofloxacin and HPMC $\mathrm{K} 100 \mathrm{M}$ were mixed thoroughly in double cone blender at $14 \pm 2 \mathrm{rpm}$ for $10 \mathrm{~min}$. Avicel PH 101 and lactose monohydrate were added to the above blend and mixed for $5 \mathrm{~min}$. The blend was granulated, using distilled water as a granulating fluid. After enough cohesiveness was obtained, the mass was sieved through ASTM 20 mesh sieve $(850 \mu)$. The granules were dried at $50^{\circ} \mathrm{C}$ for $4 \mathrm{~h}$ and thereafter kept in desiccator for $6 \mathrm{~h}$ at room temperature. The granules were lubricated for 3 min with magnesium stearate $(0.5 \% \mathrm{w} / \mathrm{w})$ and Aerosil $200 \mathrm{P}(0.5 \% \mathrm{w} / \mathrm{w})(\mathrm{ASTM}$ 60 mesh sifted). The moisture content of the lubricated granules was determined by heating the sample in hot air oven (SMC-120, Spectrum Pvt. Ltd., Mumbai, India) at $105{ }^{\circ} \mathrm{C}$. The tablets were compressed at a weight of 550 $\mathrm{mg}$ on pilot press tablet compression machine equipped with bevelled flat-faced punches $11 \mathrm{~mm}$ in diameter.

TABLE II - Composition (\%w/w) of cefixime trihydrate IR tablets (350 mg)

\begin{tabular}{clccccccccc}
\hline Sr. No. & Ingredients & C1 & C2 & C3 & C4 & C5 & C6 & C7 & C8 & C9 \\
\hline 1 & Cefixime trihydrate & 57.14 & 57.14 & 57.14 & 57.14 & 57.14 & 57.14 & 57.14 & 57.14 & 57.14 \\
2 & Avicel PH 102 & 38.86 & 36.86 & 34.86 & 38.86 & 36.86 & 34.86 & 38.86 & 36.86 & 34.86 \\
3 & Glycolys & 3 & 5 & 7 & - & - & - & - & - & - \\
4 & Ac-Di-Sol & - & - & - & 3 & 5 & 7 & - & - & - \\
5 & Polyplasdone XL & - & - & - & - & - & - & 3 & 5 & 7 \\
6 & Magnesium stearate & 0.5 & 0.5 & 0.5 & 0.5 & 0.5 & 0.5 & 0.5 & 0.5 & 0.5 \\
7 & Aerosil & 0.5 & 0.5 & 0.5 & 0.5 & 0.5 & 0.5 & 0.5 & 0.5 & 0.5 \\
\hline
\end{tabular}


TABLE III - Composition ( $\% \mathrm{w} / \mathrm{w})$ of ofloxacin sustained release tablets (550 mg)

\begin{tabular}{clcccccccc}
\hline Sr. No. & Ingredients & F1 & F2 & F3 & F4 & F5 & F6 & F7 & F8 \\
\hline 1 & Ofloxacin & 72.73 & 72.73 & 72.73 & 72.73 & 72.73 & 72.73 & 72.73 & 72.73 \\
2 & HPMC K100M & 8 & 10 & 12 & 15 & 10 & 10 & 10 & 10 \\
3 & Avicel PH 101 & 9.14 & 8.14 & 7.14 & 10.64 & 11.39 & 9.76 & 6.51 & 4.88 \\
4 & Lactose monohydrate & 9.14 & 8.14 & 7.14 & 10.64 & 4.88 & 6.51 & 9.76 & 11.39 \\
5 & Magnesium stearate & 0.5 & 0.5 & 0.5 & 0.5 & 0.5 & 0.5 & 0.5 & 0.5 \\
6 & Aerosil & 0.5 & 0.5 & 0.5 & 0.5 & 0.5 & 0.5 & 0.5 & 0.5 \\
\hline
\end{tabular}

\section{Evaluation of tablets}

Prior to compression, lubricated blend of cefixime trihydrate IR tablets and granules of ofloxacin SR tablets were characterized for physical parameters like angle of repose, bulk and tapped densities and \% compressibility $[14,15]$.The properties of the compressed tablets, such as thickness (Digital Vernier Caliper, Mitutoya Corp.), hardness (Mht-20, Monsanto Tablet Hardness Tester, Campbell Electronics, Mumbai, India), friability (EF$1 \mathrm{~W}$, Electrolab Ltd., Mumbai, India), weight variation, and disintegration time (ED-2L, Electrolab Ltd., Mumbai, India) were evaluated. The content of cefixime trihydrate in tablets was determined as per the procedure specified in USP. However, ofloxacin in tablets was determined spectrophotometrically at $293 \mathrm{~nm}$.

\section{In vitro drug release studies}

In vitro drug release studies of cefixime trihydrate IR tablets were carried out as per the specifications given in USP 30. The USP dissolution test apparatus type I (Veego Scientifics, Mumbai, India) at $100 \mathrm{rpm}$ was used for studies. The dissolution medium consisted of $0.05 \mathrm{M}$ potassium phosphate buffer pH 7.2 (900 $\mathrm{mL})$, maintained at $37 \pm 0.5^{\circ} \mathrm{C}$. An aliquot $(10 \mathrm{ml})$ was withdrawn at specific time intervals and drug content was determined by UV-visible spectrophotometer (Shimadzu 1700 (E) 23, Japan) at $289 \mathrm{~nm}$. The release profiles were compared with marketed formulation (ZIFI 200). The same conditions of in vitro dissolution as described for the studies of cefixime trihydrate IR tablets were used to study the in vitro drug release of ofloxacin SR tablets except the dissolution media used. The drug release of ofloxacin were determined under different dissolution media $\mathrm{pH} 1.2$ acidic buffer for the first $2 \mathrm{~h}, \mathrm{pH} 4.5$ acetate buffer for next hour and phosphate buffer $\mathrm{pH} 7.4$ from 4 to $24 \mathrm{~h}$. An aliquot $(10 \mathrm{ml})$ was withdrawn at specific time intervals and drug content was determined by UV-visible spectrophotometer at $293 \mathrm{~nm}$. Comparison of release profiles were carried out against marketed formulation (OF-OD).

\section{Drug release kinetic model}

To describe the kinetics of drug release from the optimized ofloxacin SR tablets, mathematical models zero-order, first order, Higuchi, Hixon-crowell, Korsmeyer-Peppas were used. The criterion for selecting the best fit model was chosen on the basis of the goodness fit test. Equations previously stated were used to determine the best fit model for release kinetics (Costa, Lobo, 2001).

\section{Formulation of cefixime trihydrate (IR) and ofloxacin (SR) bilayer tablets}

Bilayer tablets were formulated with cefixime trihydrate as IR layer and ofloxacin as SR layer. The optimized cefixime trihydrate IR tablets and ofloxacin SR tablets (similar in release profiles with marketed formulations) were selected for the development of bilayer tablets. The sustained release blend of ofloxacin (550 $\mathrm{mg}$ ) was compressed lightly Pilot press tablet machine (Chamunda Pharma Machinery Pvt. Ltd., India) equipped with $19 \mathrm{~mm}$ caplet shape, bevelled and biconcave punches. Over this compressed layer, manually the immediate release layer of cefixime trihydrate $(350 \mathrm{mg})$ was placed and compressed to obtain hardness in the range of 5-6 kg/ $\mathrm{cm} 2$ to form a bilayered tablet.

\section{Evaluation of bilayer tablets}

The properties of the compressed tablets, such as thickness, hardness, friability, weight variation, disintegration time were evaluated. The content of cefixime trihydrate and ofloxacin in bilayer tablets was determined simultaneously by using high performance thin layer chromatography (HPTLC) (CAMAG Reprostar 3 and TLC Scanner 3, CAMAG Scientific Inc., Wilmington, USA) at $\lambda_{\max } 290 \mathrm{~nm}$. 


\section{In-vitro drug release studies of bilayer tablets}

In-vitro dissolution studies of cefixime trihydrate and ofloxacin bilayer tablets were carried out separately as per the above described procedure. The withdrawn samples were analyzed simultaneously by HPTLC at $\lambda_{\max }$ $290 \mathrm{~nm}$. The dissolution profiles were compared with marketed formulations, ZIFI 200 and OF-OD for cefixime trihydrate and ofloxacin respectively.

\section{Stability studies}

The study was done to know the effect of ageing and temperature on the physical parameters, drug content and in-vitro drug release. The bilayer tablets were packed in amber colored vials sealed with bromo butyl rubber stoppers and charged at accelerated stability condition of $40 \pm 2{ }^{\circ} \mathrm{C}$ temperature and relative humidity of $75 \pm$ $5 \%$ in environmental stability chamber for the period of 3 months.

\section{RESULTS}

The FT-IR spectra of physical mixture of drugs and drugs with excipients after 30 days of accelerated stability were compared (Figures 1 and 2). The spectra showed no additional peaks compared to their individual IR spectrum of initial conditions. Also the physical appearance of the samples was not changed.

The FT-IR spectra of cefixime trihydrate and ofloxacin have shown the presence of peaks which are characteristics of the drugs structures (Table IV).

The granules of different formulations were evaluated with respect to angle of repose, bulk density, tapped density, compressibility index, moisture content and drug content. Moisture content was found in the range of $1.8-2.4 \% \mathrm{w} / \mathrm{w}$. Other parameters for granules were found to be in the acceptable range. All the blends/ granules have shown good compression properties. Drug content was found to be uniform among different batches and was more than $95 \%$. The compressed tablets were evaluated for weight variation, thickness, hardness, friability, disintegration time (for cefixime trihydrate IR tablets) and content. The weight of tablets from all the formulation batches was found within acceptable range of weight variation $( \pm 5 \%)$ as per USP. The hardness of the tablets was found in the range of $4.0-7.0 \mathrm{~kg} / \mathrm{cm}^{2}$. The disintegration time obtained for the cefixime trihydrate IR tablets was less than 1 min which was well below the limit of disintegration time of uncoated IR tablets as per the USP (i.e. not more than $15 \mathrm{~min}$ ). The tablets containing Polyplasdone XL were disintegrated at faster rate as compared to the other disintegrants used. The tablets formulated using Polyplasdone XL at 5 and $7 \% \mathrm{w} / \mathrm{w}$ concentration, disintegrated within 24 and 21 $\mathrm{s}$ respectively. Since the disintegration time observed with Polyplasdone XL containing tablets was minimum, the batches (C8 and $\mathrm{C} 9$ ) were considered for further studies. However, similarity factor (f2) was taken into consideration for the ofloxacin SR tablets. The tablets were assayed and the drug content was found within the range of $90-110 \%$ as per USP specifications. Also the tablets complied with the friability test.

When drug release from various batches (C1-C9) containing various superdisintegrants in concentration of 3,5 and $7 \% \mathrm{w} / \mathrm{w}$ was compared, it was found that $\mathrm{C} 8$ and C9 batches containing Polyplasdone XL releases drug more promptly and completely within $30 \mathrm{~min}$. So these batches were compared for drug release from reference product (ZIFI 200). From the in vitro drug release data (Figure 4), it can be seen that the drug release profile of tablets from $\mathrm{C} 8$ batch was matching completely with the ZIFI 200. However, the $\mathrm{C} 9$ batch released drug at faster rate. Hence, C8 batch formulation was considered as optimized and was used further for the development of bilayer tablets.

Dissolution study data of ofloxacin SR tablets and OF-OD tablets demonstrated that increased concentration of HPMC K100M lead to the decreased release of ofloxacin. As the amount of lactose monohydrate was increased, drug release was also increased which may be due to the hydrophilic nature of lactose incorporated in the formulation. All the above studied parameters indicated that the batch F8 where lactose monohydrate and Avicel PH 101 were used in 1:4 ratio and HPMC in $10 \% \mathrm{w} / \mathrm{w}$ concentration was found to be best suited for the formulation of SR layer in bilayer tablets (Figure 5) since it has the highest $\mathrm{f} 2$ value of 87.01 when compared with other formulation batches. Hence, F8 formulation was considered as optimized and used further for the development of bilayer tablets.

The optimized formulation batch (F8) has shown Korsmeyer-Peppas as a best fit drug release kinetic model (Table V). The release exponent value (n) was found to be 0.7921 . The dominant mechanism for drug release through matrix systems was found to be anomalous transport. The cefixime trihydrate (IR) and ofloxacin (SR) bilayer tablets were formulated using optimized batches C8 and F8. The physical parameters of evaluation of bilayer tablets are shown in Table VI All the physical parameters of the tablets were well within the range.

The Cefixime trihydrate IR layer of bilayer 


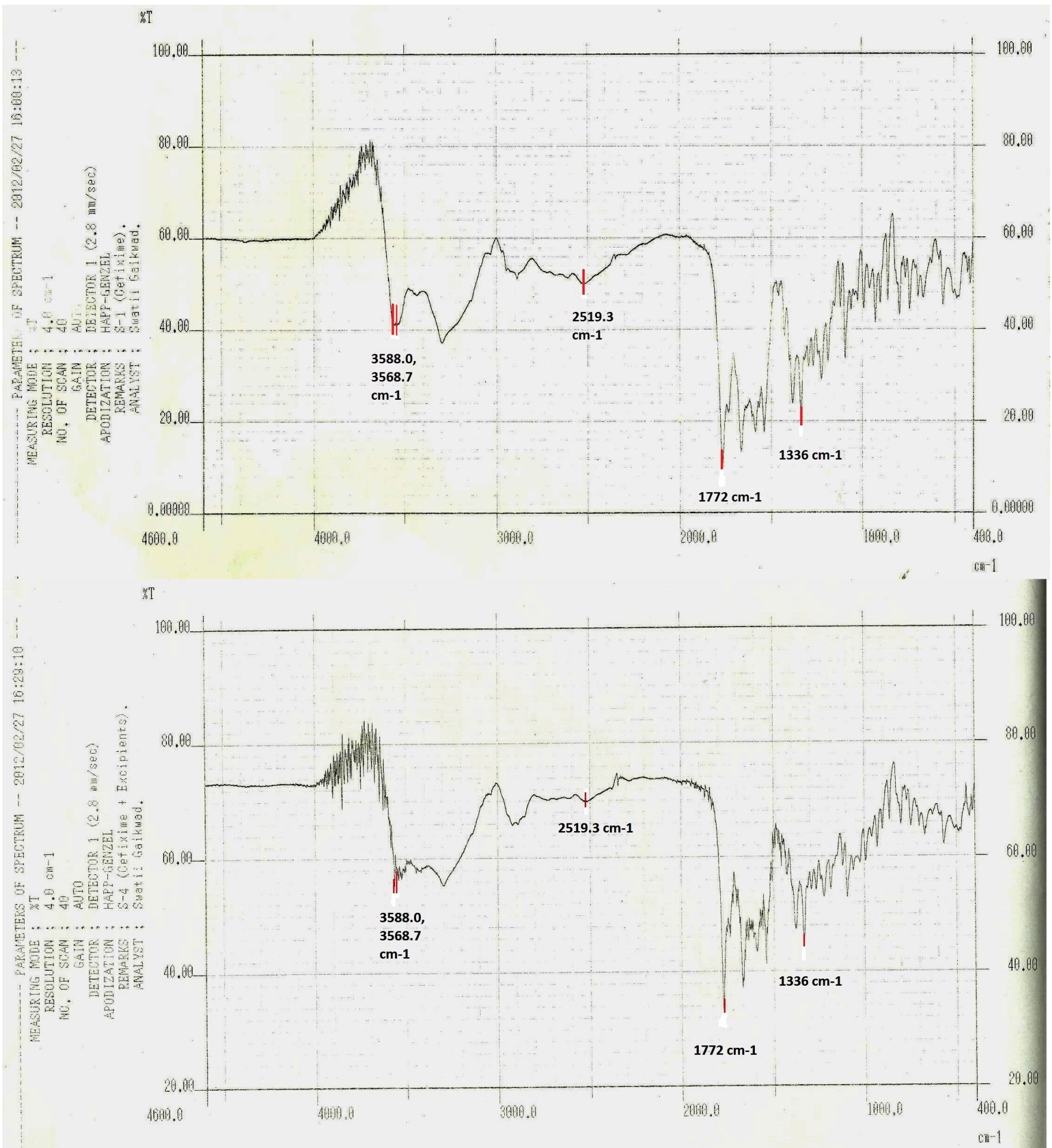

FIGURE 1 - Infra red (FT-IR) spectrum of cefixime trihydrate and cefixime trihydrate with excipients.

tablets formulated from the blend of C8 formula have shown the disintegration time of $30 \mathrm{sec}$. In-vitro dissolution study of bilayer tablets were performed using USP type I apparatus (Table $7 \& 8$ show the percent drug release)and amount of drug released was calculated simultaneously using HPTLC (representative densitogram is shown in Figure 3).Cumulative \% drug released as a function of time plotted for Cefixime trihydrate and Ofloxacin were compared with their marketed products (Figures 4 and 5). Three months of accelerated stability studies show no significant effect on the drug release profile (Figures 6 and 7).The other 


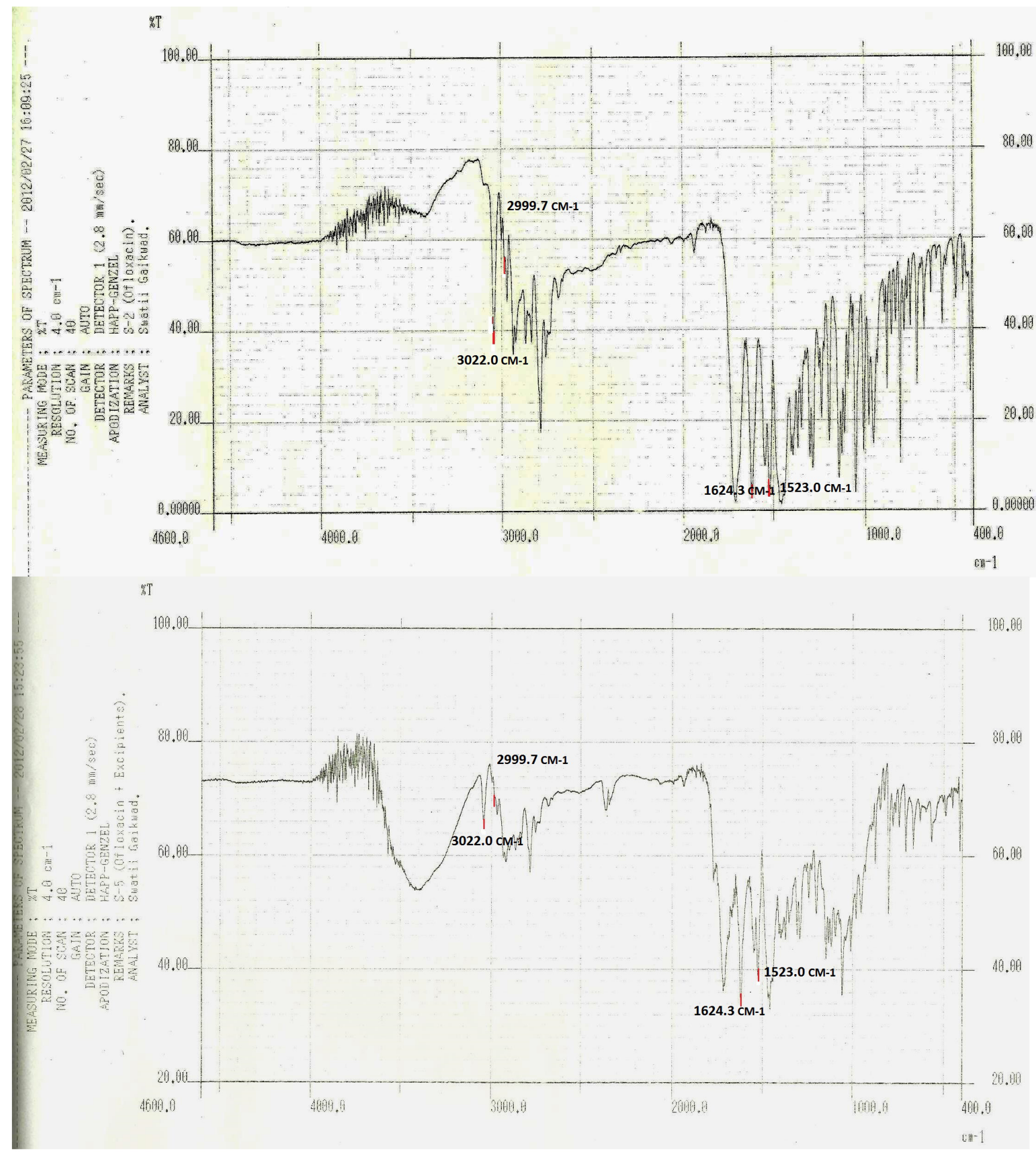

FIGURE 2 - Infra red (FT-IR) spectrum of ofloxacin and ofloxacin with excipients.

physical parameters were also found to be stable after a three month stability study (Table IX).

\section{DISCUSSION}

The FT-IR spectrum confirms that no interaction was observed between drug-drug as well as drugs with disintegrants, microcrystalline cellulose and HPMC, which were used in the development of the formulations. The values of angle of repose indicated satisfactory flow behavior. It is considered that the disintegration is the first step in the dissolution of immediate release 
TABLE IV - Drug characterization by IR-Spectroscopy

\begin{tabular}{ccccc}
\hline \multirow{2}{*}{ Sr. No. } & \multicolumn{2}{c}{ Drug characterization of cefixime trihydrate } & \multicolumn{2}{c}{ Drug characterization of ofloxacin } \\
\cline { 2 - 5 } & Wave number $\left(\mathbf{c m}^{-1}\right)$ & Functional group & Wave number $\left(\mathbf{c m}^{-1}\right)$ & Functional group \\
\hline \multirow{2}{*}{3} & $3588.0,3568.7$ & primary and secondary & 3022.0 & alkene group \\
$\mathbf{2}$ & 2519.3 & amines & 2999.7 & aromatic rings \\
$\mathbf{3}$ & 1772 & nitrile group & 1624.3 & aryl carboxylic acid \\
$\mathbf{4}$ & 1336 & carboxylic acid & 1523 & halogen compound C-F \\
\hline
\end{tabular}

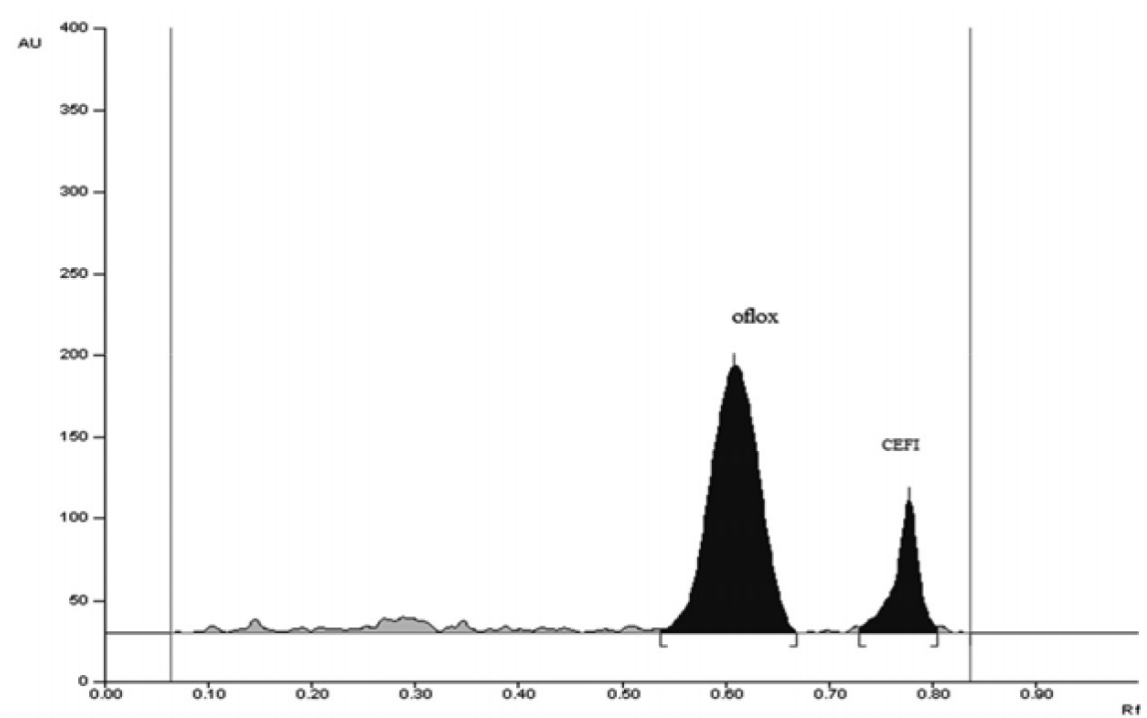

FIGURE 3 - Representative densitogram of mixed standard solution of ofloxacin $(200 \mathrm{ng} / \mathrm{band}, \mathrm{Rf}=0.61 \pm 0.10)$ and cefixime trihydrate $(200 \mathrm{ng} / \mathrm{band}, \mathrm{Rf}=0.78 \pm 0.12)$.

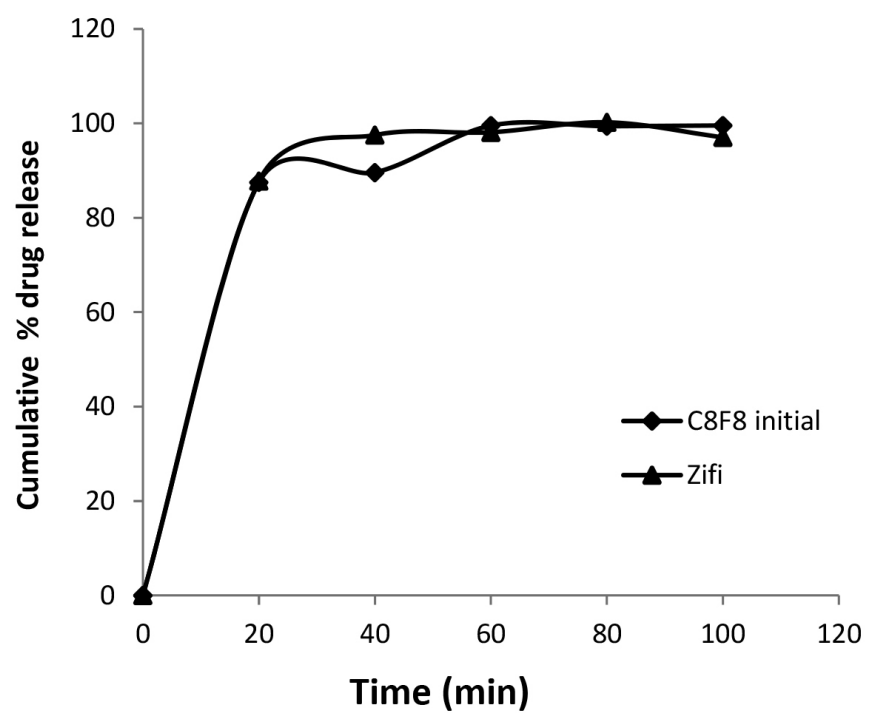

FIGURE 4 - Cumulative percentage of cefixime trihydrate released versus time (50 min) in $\mathrm{pH} 7.2$ phosphate buffer, 900 $\mathrm{ml}$ at $100 \mathrm{rpm}$ using USP type I dissolution test apparatus (mean $\pm \mathrm{SD}, \mathrm{n}=6$ ). $\mathrm{C} 8 \mathrm{~F} 8$ (Initial), data of initial condition and ZIFI 200, marketed reference product. tablets. Relating friability, disintegration time and rate of dissolution parameters, it was observed that increase in friability does not affect much disintegration time of tablets, that may be due to the use of superdisintegrants. Moisture content indicated optimum drying of granules. Korsmeyer-Peppas release kinetic model was found to be the best fit drug release kinetic model for F8 batch which states that the release mechanism is not well known or more than one type of release phenomena could be involved. The dissolution study suggested that the cefixime trihydrate immediate release layer has released more than $85 \%$ of drug within 10 min which was desired and was matching in release profile with the reference product. The complete release was observed within 30 min of the dissolution study. The release of ofloxacin from SR layer of bilayer tablets was also compared with the reference product (OZ-OD). The initial similarity factor (f2) value was found to be close with similarity factor (f2) value after stability study.

The evaluation of physical parameters of tested batches has not shown any significant effect after 3 months 
TABLE V - Drug release models for optimized batch

\begin{tabular}{lcccccc}
\hline \multicolumn{7}{c}{ REGRESSION COEFFICIENT } \\
\hline $\begin{array}{l}\text { Formulation } \\
\text { Code }\end{array}$ & $\begin{array}{c}\text { Zero order } \\
\text { plots } \\
\text { (r2) }\end{array}$ & $\begin{array}{c}\text { First order } \\
\text { plots } \\
(\mathbf{r} 2)\end{array}$ & $\begin{array}{c}\text { Higuchi } \\
\text { plots } \\
(\mathbf{r} 2)\end{array}$ & $\begin{array}{c}\text { Korsemeyer- } \\
\text { peppas plots } \\
(\mathbf{r} 2)\end{array}$ & $\begin{array}{c}\text { Hixson-crowells } \\
\text { plots } \\
\text { (r2) }\end{array}$ & $\begin{array}{c}\text { Slope } \\
\text { (n) }\end{array}$ \\
\hline F8 & 0.9792 & 0.9385 & 0.9189 & 0.9826 & 0.9786 & 0.7912 \\
\hline
\end{tabular}

TABLE VI - Evaluation parameters of bilayer tablets

\begin{tabular}{|c|c|c|c|c|c|c|}
\hline \multirow[b]{2}{*}{ Parameters } & \multirow[b]{2}{*}{$\begin{array}{c}\text { Weight variation } \\
(\%)\end{array}$} & \multirow[b]{2}{*}{$\begin{array}{l}\text { Thickness } \\
\text { (mm) }\end{array}$} & \multirow[b]{2}{*}{$\begin{array}{c}\text { Hardness } \\
\left(\mathbf{k g} / \mathrm{cm}^{2}\right)\end{array}$} & \multirow[b]{2}{*}{$\begin{array}{c}\text { Friability } \\
(\%)\end{array}$} & \multicolumn{2}{|c|}{ Content uniformity (\%) } \\
\hline & & & & & $\begin{array}{l}\text { Cefixime } \\
\text { trihydrate }\end{array}$ & Ofloxacin \\
\hline $\mathrm{C} 8 \mathrm{~F} 8$ & \pm 4.27 & $7.8 \pm 0.08$ & $5-6$ & 0.14 & $99.54 \pm 0.45$ & $98.25 \pm 1.65$ \\
\hline
\end{tabular}

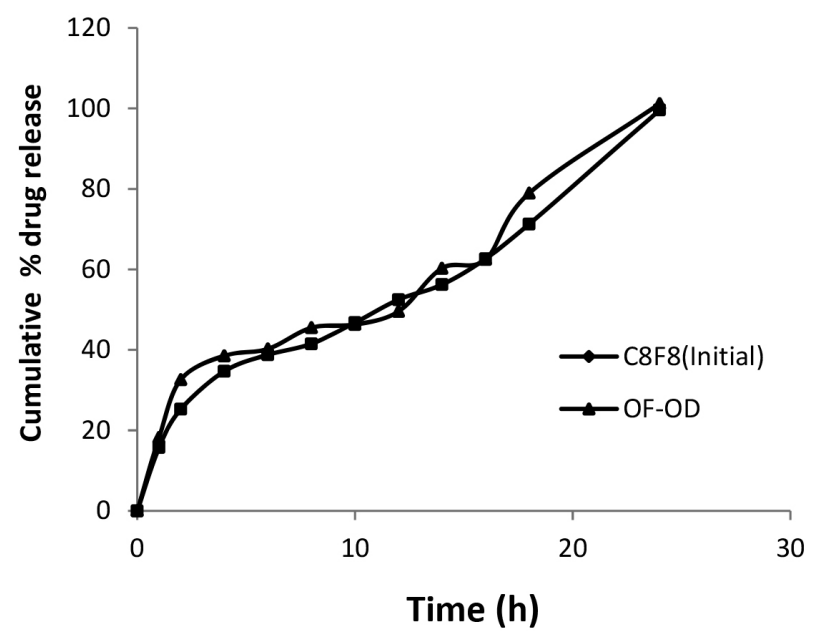

FIGURE 5 - Cumulative percentage of ofloxacin released versus time (hour) in $\mathrm{pH} 1.2$ buffer for 2 hour, $\mathrm{pH} 4.5$ acetate buffer for next hour and $\mathrm{pH} 7.4$ phosphate buffer $900 \mathrm{ml}$ at $100 \mathrm{rpm}$ using USP type I dissolution test apparatus (mean $\pm \mathrm{SD}, \mathrm{n}=6$ ) for remaining hours. C8F8 (Initial), data of initial condition and OF-OD, marketed reference product.

of accelerated stability studies (Figures 6 and 7). The drug content of the bilayer tablets was also found to be within the specification of USP. The batches also have not shown differences in the drug release profiles. Hence, it can be concluded that the formulated bilayer tablets were stable for the given condition and period of stability.

The combination of cefixime and ofloxacin has been documented to have dual mode of action. Ofloxacin prevents nucleic acid synthesis and cefixime inhibits cell wall synthesis, hence less chance for microbes to develop resistance against combination of antibiotics cefixime trihydrate showed similar release profiles invitro under acidic conditions to those of the immediate release cefixime trihydrate tablets (ZIFI 200) developed

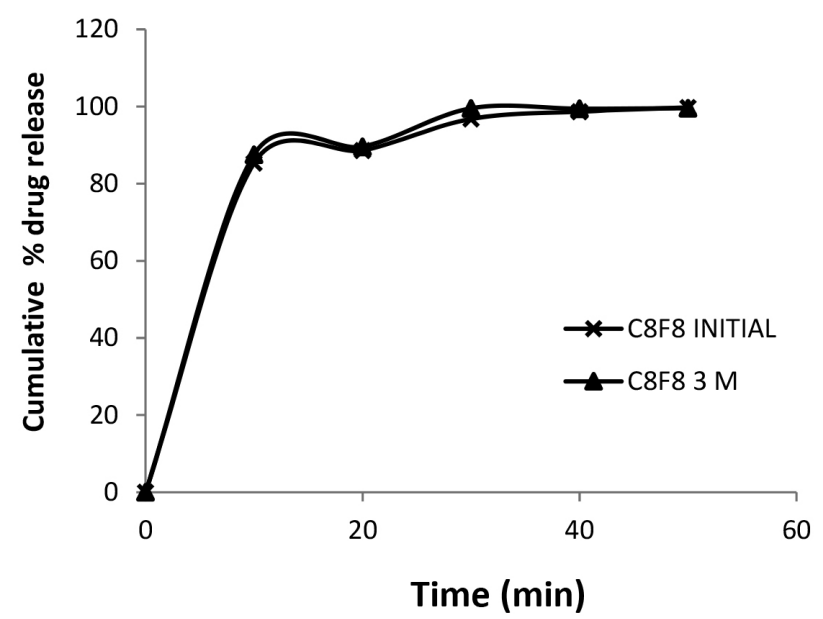

FIGURE 6 - In vitro drug release study of cefixime trihydrate from bilayer tablets before and after 3 months.

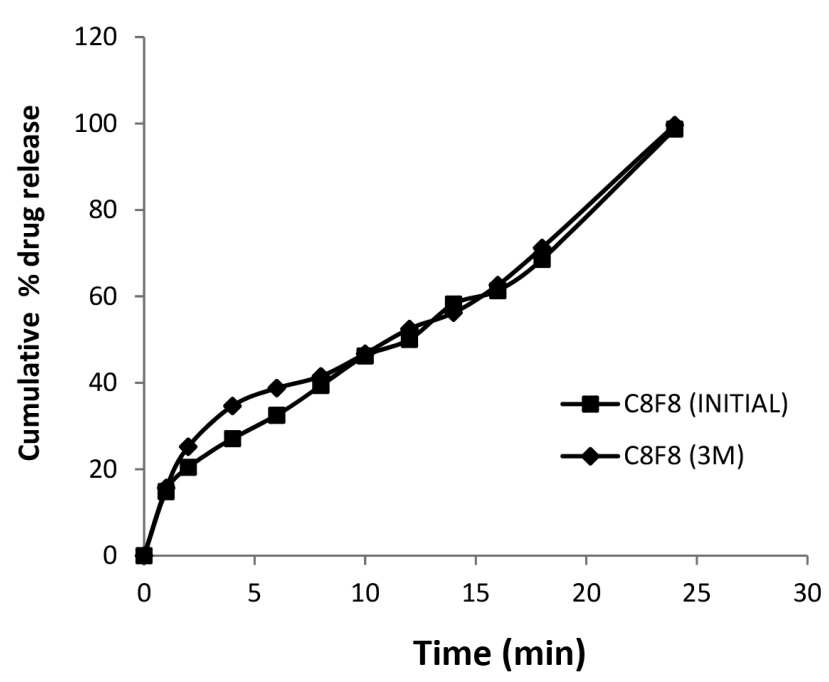

FIGURE 7 - In vitro drug release study of ofloxacin from bilayer tablets before and after 3 months. 
by an Indian company. Ofloxacin sustained release layeron the other hand showed an improvementin the release of ofloxacin in vitro compared with that of ofloxacin SR tablets (OF-OD). This release profile is beneficial, as it releases cefixime immediately for faster action and ofloxacin slowly for the longer duration of time to maintain

TABLE VII - Dissolution data of cefixime trihydrate in bilayer tablets

\begin{tabular}{cc}
\hline Time (min) & C8F8 \\
\hline 0 & 0 \\
10 & $87.52 \pm 0.43$ \\
20 & $89.57 \pm 0.51$ \\
30 & $99.53 \pm 0.49$ \\
40 & $99.42 \pm 0.44$ \\
50 & $99.55 \pm 0.51$ \\
\hline
\end{tabular}

TABLE VIII - Dissolution data of ofloxacin in bilayer tablets $(\mathrm{n}=3)$

\begin{tabular}{cc}
\hline Time (h) & C8F8 \\
\hline 1 & $15.69 \pm 1.18$ \\
2 & $25.24 \pm 1.21$ \\
3 & $34.68 \pm 1.11$ \\
4 & $38.79 \pm 1.02$ \\
5 & $41.52 \pm 1.05$ \\
6 & $46.77 \pm 0.95$ \\
7 & $52.49 \pm 1.28$ \\
8 & $56.22 \pm 1.42$ \\
9 & $62.63 \pm 1.20$ \\
10 & $71.25 \pm 1.15$ \\
& $2499.63 \pm 1.19$ \\
\hline
\end{tabular}

a steady state concentration of drug in blood.

Formulating cefixime trihydrate as immediate release and ofloxacin as sustained release layer in a bilayer tablet reduces the frequency of administration and dose of the drugs. Reduced dose of the drug automatically will tend to reduce the adverse effect of the drug.

Successful bilayer tablet formulation containing the antibiotics cefixime trihydrate ofloxacin were developed for once a day administration for treatment of sexually transmitted diseases.

\section{CONCLUSION}

Thus from the result, it can be concluded that the bilayer tablets containing $200 \mathrm{mg}$ of cefixime trihydrate as immediate release component and $400 \mathrm{mg}$ ofloxacin as sustained release component has successfully developed. Also, the release from the developed formulations was comparable to the marketed drug formulations. The developed bilayer tablets were stable in the accelerated stability conditions. The results of current study clearly show that bilayer tablet was developed as a stable dosage form. cefixime trihydrate and ofloxacin bilayer tablet has a promising potential as an alternative to the conventional dosage form. This new dosage form has commercial marketing potency as no such delivery systems are presently available in market.

\section{ACKNOWLEDGEMENTS}

We are thankful to UGC, New Delhi, Government of India for providing fellowship. We are very much grateful to Zim Laboratories Ltd. (Nagpur, India) and Vama Pharma (Nagpur, India) for providing the gift samples of drug, Cefixime trihydrate and Ofloxacin respectively.

TABLE IX - Evaluation parameters of stability batch (C8F8)

\begin{tabular}{lcccc}
\hline Evaluation parameters & $\begin{array}{c}\text { Before stability } \\
\text { storage }\end{array}$ & $\begin{array}{c}\text { After 1 month } \\
\text { storage }\end{array}$ & $\begin{array}{c}\text { After 2 months } \\
\text { Storage }\end{array}$ & $\begin{array}{c}\text { After 3 months } \\
\text { storage }\end{array}$ \\
\hline Hardness $\left(\mathrm{kg} / \mathrm{cm}^{2}\right)$ & $5-6$ & $6 \pm 1.1$ & $5.8 \pm 1.6$ & $5.5 \pm 1.1$ \\
Friability (\%) & 0.136 & $0.5 \pm 0.6$ & $0.6 \pm 0.3$ & $0.6 \pm 0.4$ \\
Weight variation (\%) & 4.2 & 2.4 & 2.7 & 3.0 \\
$\begin{array}{l}\text { Disintegrating time of cefixime trihydrate layer } \\
\text { in seconds }\end{array}$ & 25 & $24 \pm 1$ & $21 \pm 2$ & $23 \pm 1$ \\
$\begin{array}{l}\text { Drug content (\%) } \\
\text { \% drug release of (cefixime layer ) }\end{array}$ & $99.54 \pm 0.45$ & $97.04 \pm 1.8$ & $96.89 \pm 2.0$ & $96.80 \pm 2.4$ \\
\% drug release of (ofloxacin layer ) at the end & $98.25 \pm 1.65$ & $97.98 \pm .2 .7$ & $97.87 \pm 3.2$ & $95.69 \pm 2.1$ \\
of 24hr & $99.55 \pm 0.51$ & $97.05 \pm 1.9$ & $96.77 \pm 1.4$ & $96.11 \pm 1.8$ \\
\hline
\end{tabular}




\section{REFERENCES}

BENNETT, P.N.; BROWN, M.J. Antibacterial drugs. In: . Clinical Pharmacology. 10. ed. Edinburg:

Churchill Livinstone, 2008. p.188-207.

BURSTEIN. G.R.; GAYDOS. C.A.; DIENER-WEST. M.; HOWELL. M.R.; ZENILMAN. J.M.; QUINN, T.C. Incident Chlamydia trachomatis infections among inner-city adolescent females. JAMA, v.280, 521-526, 1998.

CHAVANPATIL, M.; JAIN, S. CHAUDARI, S.; SHEAR, R.; VAVIA, P. Development of sustained release gastroretentive drug delivery system for Ofloxacin: in-vitro and in-vivo evaluation. Int. J. Pharm., v.304, n.1-2, p.178-184, 2005.

COSTA, P.; LOBO. J.M.S. Modeling and comparison of dissolution profiles. Eur. J. Pharm. Sci., v.13, n.2, p.12333, 2001.

DALLABETTA. G.A.; GERBASE. A.C.; HOLMES. K.K. Problems, solutions, and challenges in syndromic management of sexually transmitted diseases, Sex Transm Inf. 74, S1-S11,1998.

DIVYA, A.; KAVITHA, K.; KUMAR, R.M.; DAKSHAYANI, S.; JAGADEESH, S. Bilayer tablet technology: an overview. J. Appl. Pharm. Sci., v. 1, n.8, p.43-47, 2011.

GERBASE, A.C.; ROWLEY, J.T.; HEYMANN, D.H.; BERKLEY, S.F.; PIOT, P. Global prevalence and incidence estimates of selected curable STDs. Sex Transm. Infect.,v.74, S12-S16, 1998.

HANDSFIELD, H.H. Problems in the treatment of bacterial sexually transmitted diseases. Sex Trans. Dis., v.13, p.17984, 1986.

KIDD, S.E.; WORKOWSKI, K. Sexualy Transmited Diseases. In: BRUNETTE, G.W et al. CDC health information for international travel 2016: the yellow book. New York: Oxford University Press, 2016. Available at: <http:// wwwnc.cdc.gov/travel/yellowbook/2016/infectiousdiseases-related-to-travel/sexually-transmitted-diseases $>$. Accessed on: 10 July 2016.

KUKSAL, A.; TIWARY, A.K.; JAIN, N.K.; JAIN, S. Formulation and in-vitro, in-vivo evaluation of extendedrelease matrix tablet of zidovudine: influence of combination of hydrophilic and hydrophobic matrix formers. AAPS PharmSciTech.,v.7, n.1, E1-E9, 2006.
PARASHAR, A.; GUPTA, B.P.; BHARDWAJ, A.K.; SARIN, R. Prevalence of RTIs among women of reproductive age group in Shimla city. Indian J. Comm. Med., v.31, n.1, p.15-17, 2006.

PATEL, A.R.; PRAJAPATI, D.S.; RAVAL, J.A. Fast dissolving films (Fdfs) as a newer venture in fast dissolving dosage forms. Int. J. Drug Dev. Res., v.2, n.2, p.232-234, 2010.

PICCO, M.F. Digestion: How long does it take? [Internet text]. 2012. Available at: $<$ http://www.mayoclinic.org/digestivesystem/expert-answers/faq-20058340>. Accessed on: 10 July 2016.

RAO. P.; MOHAMEDALI. F.Y.; TEMMERMAN. M.; FRANSEN. L.Systematic analysis of STD control: an operational model. Sex Transm. Infect., v.74, S17-S22, 1998.

REDDY, K.R.; MUTALIK, S.; REDDY, S. Once-daily sustained-release matrix tablets of nicorandil: formulation and in vitro evaluation. AAPS PharmSciTech., v.4, n.4, p.480-488, 2003.

REMYA, K.S.; BEENA, P.; BIJESH, P.V.; SHEEBA, A. Formulation development, evaluation and comparative study of effects of super disintegrants in cefixime oral disintegrating tablets. J Young Pharm., v.2, n.3, p.234-239, 2010.

ROBERT, N.A.; STRICK, N.; LI, Y.; LIN, K.; JIANG, S. Design of a "microbicide" for prevention of sexually transmitted diseases using "inactive" pharmaceutical excipients. Biologicals, v.27, n.1, p.11-21, 1999.

SCHMIDT, J.; CHARLES, V.P. Antibiotic use in the emergency department. III. The quinolones, new beta lactams, beta lactam combination agents, and miscellaneous antibiotics. J. Emerg. Med., v.14 ,n.4, p.483-496,1995.

SICA, D.A. Fixed-dose combination antihypertensive drugs. Do they have a role in rational therapy? Drugs, v.48, n.1, p.16-24, 1994.

STEEN,R.; CHERSICH, M.; GERBASE, A.; NEILSEN, G.; WENDLAND, A.; NDOWA, F.; AKL, E.A.; LO, Y.R.; DE VLAS, S.J. Periodic presumptive treatment of curable sexually transmitted infections among sex workers: a systematic review. AIDS, v.26, n.4, p.437-445, 2012. 
TREE, D.L.; MORSE, S.A. Chancroid and Haemophilus ducreyi: an update. Clin. Microb. Rev., v.8, n.3, p.357-375, 1995.

WORLD HEALTH ORGANIZATION. WHO. Estimation of the incidence and prevalence of sexually transmitted infections. Report of a WHO consultation. Treviso, Italy, 2002.
YUE, C.; YU, Z.; XING, T. In-vitro and in-vivo evaluation of Ofloxacin sustained release pellets. Int. J. Pharm., v.360, n.1-2, p.47-52, 2008.

Received for publication on $24^{\text {th }}$ October 2015 Accepted for publication on $15^{\text {th }}$ August 2016 